\title{
Can Total Antioxidant Capacity Predict Clomiphene Citrate Resistance in Polycystic Ovary Syndrome Patients?
}

\author{
Polikistik Over Sendromlu Hastalarda Total Antioksidan Düzeyi Klomifen Sitrat Direncini Öngörebilir mi?
}

\author{
Hasan Cilgin ${ }^{1}$ \\ ${ }^{1}$ Department of Obstetrics and Gynecology, Kafkas University Faculty of Medicine, Kars, Turkey
}

\begin{abstract}
Aim: Previous studies have shown that oxidative stress may be associated with polycystic ovary syndrome (PCOS) as well as infertility and that antioxidant treatments can increase fertility rates. Therefore, it was aimed to investigate whether total antioxidant levels were useful in predicting clomiphene citrate (CC) resistance in infertile polycystic ovary syndrome patients.
\end{abstract}

Material and Method: Seventy-seven (77) participants (45 sensitive and 32 resistant) with polycystic ovary sendrome who met study criteria were between 20 and 35 years of age and their partners had normal spermiograms. Clomiphene citrate was given to all patients up to three cycles between three and seven days of their menstrual cycle, starting with a $50 \mathrm{mg} /$ daily dose. If ovulation did not provided dose was raised to 100 and $150 \mathrm{mg}$ in subsequent cycles. Plasma Total antioxidant status (TAS) was determined using an automated measurement method. The CC sensitive group was compared with the $C C$ resistant group in terms of total antioxidant levels.

Results: Mean plasma total antioxidant levels were $1.21 \pm 0.42$ and $2.4 \pm 0.49 \mathrm{mmo} / \mathrm{Trol} E \mathrm{~g} / \mathrm{L}$ in the $\mathrm{CC}$ resistant and sensitive groups, respectively $(p=0.001)$. In the receiver operating characteristic (ROC) curve analysis while total antioxidant status value was $\leq 1.66$ $\mathrm{mmol}$ Trolox equivalent/L had predictability on resistance development with $93.75 \%$ sensitivity and $86.67 \%$ specificity.

Conclusion: Total antioxidant level was lower in infertile polycystic ovary syndrome patients who were resistant to CC treatment. Therefore, total antioxidant levels could be a useful marker in establishing CC resistance.

Key words: clomiphene resistance; ovulation induction; polycystic ovary syndrome; reactive oxygen species; total antioxidant status

\section{ÖZET}

Amaç: Önceki çalıșmalar oksidatif stresin polikistik over sendromu (PKOS) yanı sıra infertilite ile ilișkili olabileceğini ve antioksidan tedavilerin fertilite oranlarını artırabileceğini göstermiștir. Bu nedenle, infertil polikistik over sendromlu hastalarda total antioksidan seviyelerinin klomifen sitrat (KS) direncini öngörmede faydalı olup olmadığının araștırıması amaçlandı.
Materyal ve Metot: Çalıșma kriterlerini karșılayan ve polikistik over sendromu olan yetmiș yedi (77) katıımcının (45 duyarlı ve 32 dirençli), yașları 20-35 arasındaydı ve partnerlerinin spermiyogramları normaldi. Klomifen sitrat, menstrüel sikluslarının 3-7. günleri arasında, 50 mg/günlük dozla bașlanarak, üç siklusa kadar tüm hastalara verildi. Eğer ovulasyon sağlanmadıysa, verilen doz sonraki sikluslarda 100 ve 150 mg'a kadar yükseltildi. Plazma Total antioksidan durumu (TAD) otomatik bir ölçüm yöntemi kullanılarak belirlendi. KS'ye duyarlı grup ile KS'ye dirençli grup, total antioksidan düzeyleri açısından karșılaștırıldı.

Bulgular: Ortalama plazma total antioksidan seviyeleri KS dirençli ve duyarlı gruplarda sırasıly 1,21 $\pm 0,42$ ve 2,4 0 0,49 mmo/TrolEq/L idi ( $p=0,001)$. ROC eğrisi analizinde, total antioksidan durum değeri $\leq 1,66$ mmolTrolEq/L iken direnç gelișimi için \%93,75 duyarlılık ve \%86,6 özgüllük ile öngörülebilirlik elde edildi.

Sonuç: KS tedavisine dirençli olan infertil polikistik over sendromu hastalarında total antioksidan düzeyi daha düșüktü. Bu nedenle, total antioksidan düzeyleri KS direncinin saptanmasında yararlı bir belirteç olabilir.

Anahtar kelimeler: klomifene direnç; ovulasyon indüksiyonu; polikistik over sendromu; reaktif oksijen türleri; total antioksidan durumu

\section{Introduction}

Polycystic ovary syndrome (PCOS) is one of the most common endocrine and metabolic disorders, affecting $6-14 \%$ of reproductive age women ${ }^{1}$. This endocrinopathy is characterised by oligomenorrhea, ovarian cystic follicles, insulin resistance (IR), hyperinsulinemia, hyperandrogenism, increased luteinizing hormone (LH), obesity, diabetes and chronic anovulation with infertility ${ }^{2}$. In spite of not being well defined, IR has a main role in the pathogenesis of PCOS, according to

IIletișim/Contact: Hasan Calgın, Kafkas University Faculty of Medicine, Department of Obstetrics and Gynecology • Tel: 05332279980 • E-mail:munzurluhasan@yahoo.com • Geliș/Received:22.11.2019 • Kabul/Accepted:11.05.2020

ORCID: Hasan Çılgin, 0000-0002-7279-5995 
previous studies; in addition hyperinsulinemia appears because of IR, and oxidative stress emerges in diabetic patients because of a reduction in antioxidant status ${ }^{3,4}$. Accumulating arguments have shown that oxidative stress induced by reactive oxygen species (ROS) may contribute to the development of the main characteristics of PCOS, such as IR and hyperandrogenism ${ }^{5}$. Many studies conducted on obese patients have shown that levels of reactive oxygen species or oxidant products have increased. In addition, in PCOS visceral adiposity increases, this is associated with co-morbidities of this syndrome such as dyslipidemia, hyperglycemia and $\mathrm{IR}^{6-8}$.

The various features and relationships of PCOS, such as androgen excess, abdominal adiposity, insulin resistance and obesity may contribute to the development of local and systemic oxidative stress that can mutually worsen those metabolic abnormalities ${ }^{9,10}$. A systematic review and meta-analysis showed that oxidative stress markers in several circulations were abnormal, regardless of excess weight in women with PCOS. Although modest in magnitude, these abnormalities suggest that oxidative stress may be involved in the pathophysiology of this common disease ${ }^{11}$. As shown by several preceding works, however, women with PCOS demonstrate reduction in antioxidant status. As a few previous studies have shown, women with PCOS show reduced antioxidant status and increased oxidative stress status. The physiological levels of ROS in the reproductive system of women play a fundamental role in folliculogenesis and oocyte maturation and may also affect the results of assisted reproductive techniques ${ }^{12,13}$. In addition, excessive production of ROS in ovarian follicular fluid may have adverse effects on the above mentioned procedures ${ }^{14}$.

In the presence of limited antioxidant defence, the imbalance resulting from excessive oxidant formation is defined as oxidative stress ${ }^{15}$. High reactive oxygen species levels in granulose cells correlate with low oocyte fertilization ability, low embryo quality and reduced implantation rates. Oxidative stress is considered related to the pathology of reproduction and development ${ }^{16}$.

One of the first step pharmacological agents in the induction of ovulation in anovulatory PCOS cases is clomiphene citrate (CC). In PCOS patients with the CC treatment ovulation is obtained in $80 \%$ of the cases, half of which result in pregnancy. Factors that play a role in the etiology of $\mathrm{CC}$ resistance are still unclear, however, despite the maximum treatment dose of 150 $\mathrm{mg}$ /day; those who do not ovulate are defined as CC resistant patients ${ }^{17}$.

The role of oxidative stress in infertility has been demonstrated and fertility rates can be increased with antioxidant treatments. In light of these data, I aimed to investigate whether the total antioxidant capacity in infertile patients with polycystic ovary syndrome was useful in predicting clomiphene citrate resistance in ovulation induction.

\section{Material and Method}

\section{Study Design}

Seventy seven infertile women with PCOS (32 resistant to CC and 45 sensitive to CC) aged 20-35 years, nonobese, with normal insulin sensitivity based on of clinical and laboratory criteria were recruited and registered. PCOS diagnosis was based on the 2003 ESHRE/ASRM diagnostic criteria; patients who had at least two of the following conditions were accepted as having polycystic ovary syndrome: oligo or anovulation, clinical and/or biochemical signs of hyperandrogenism or polycystic ovarian morphology. Other anovulation cases were excluded; thyroid dysfunction, hyperprolactinemia, pregnancy, past ovarian surgical history, hypothalamic amenorrhea, premature ovarian failure, type 1 diabetes, androgen-secreting tumours or ovarian tumour, Cushing syndrome and congenital adrenal hyperplasia were taken into consideration. Before initiating ovulation induction with CC clinical, sonographic, and endocrine screening were performed. Age, infertility and cycle history, body mass index, previous medications and/or surgeries were considered for clinical screening.

Unless pregnancy was not achieved clomiphene citrate (Klomen 50 mg, Kocak Farma, Istanbul, Turkey) was administered at a daily dose of $50 \mathrm{mg}$ (when ovulation was not provided dose was raised to 100 and $150 \mathrm{mg}$ in subsequent cycles) for three cycles, three to seven day after initiation of spontaneous or progestininduced withdrawal bleeding. Patients diagnosed with dominant follicle under ultrasound evaluation (when $\geq 1$ follicle reached $\geq 18-20 \mathrm{~mm}$ ) were subjected to 10.000 IU human chorionic gonadotropin (hCG) (Choriomon, IBSA, Lugano, Switzerland) and ovulation was assessed by midluteal ( 21 days) serum progesterone measurement $(>10 \mathrm{ng} / \mathrm{ml})$, combined with visualization of the preovulatory follicle on transvaginal 
ultrasonography $\geq 18 \mathrm{~mm}$ mean diameter and subsequent rupture. If ovulation was observed, the dose was not increased in subsequent cycles. The follow-up period for all patients included in the study was at least three treatment cycles unless pregnancy was provided. The first ovulation after CC was determined as the last point. Good responders were defined as patients who ovulated after CC, independent of the dose administered. Treatment cycles number and the first ovulation at which CC dose was observed were noted. Despite the maximum treatment dose of $150 \mathrm{mg} /$ day, those who did not ovulate were defined as CC-resistant anovulatory patients.

While creating exclusion criteria; negative postcoital test, any tubal or peritoneal factor, previous CC or gonadotropin treatment, history of ovarian surgery were considered. Women who were under 20 years of age and over 35 years of age were excluded from the study, as well as those using drugs affecting ovarian function until 6 months. Patients with an infertile partner who did not meet the criteria of World Health Organization in terms of concentration, mobility and/or morphology were also excluded from the study. Patients with a diet, smoking, systemic disease and without oligo or amenorrhea were also excluded.

Concentration of estradiol $\left(\mathrm{E}_{2}\right)$, follicle stimulating hormone $(\mathrm{FSH})$, luteinizing hormone (LH), progesterone, testosterone, androstenedione (AS), dehydroepiandrosterone sulphate (DHEA-S) and the total antioxidant status (TAS) were evaluated and compared in the CC sensitive and resistant groups.

Blood samples were collected from both groups before the treatment on day three of their menstrual cycle between 9.00 and 10.00 a. m., after an overnight fast. The samples were centrifuged two hours after withdrawal and assessed the same day. FSH, LH, E $E_{2}$ AS, DHEA-S, progesterone and testosterone were measured in Immulite 2006 (IEMA; Diagnostic Products Corporation, Los Angeles, USA). The plasma TAS was determined using an automated measurement method, developed by Erel ${ }^{18}$. This method is based on the loss of blue and green colour according to antioxidant concentration and antioxidant capacity level of 2.2'-azino-di- (3-ethylbenzthiazoline sulfonate) (TAS-liquid stable kit; Fortress Diagnostics Limited, $\mathrm{UK}$ ) which is a more stable radical cation. This colour change was assessed by measuring the absorbance value at $660 \mathrm{~nm}$. The results were expressed in $\mathrm{mmol}$ troloxequivalent/L.

\section{Statistical Analysis}

Statistical analysis was carried out using the SPSS version 20 (SPSS IBM, New York, U. S. A). Demographic and biological measures were summarised as means ( \pm standard deviation) and categorical data were summarised as percentages. Differences among groups were evaluated using Student's t test. For serum total antioxidant levels, a receiver operating characteristic curve analysis was used to establish the cut-off values for optimising the CC resistance prediction. Sensitivity and specificity were then calculated. In addition, areas under the curves (AUC) were evaluated for total antioxidant levels. A value of $\mathrm{p}<0.05$ was considered statistically significant.

\section{Ethical Approval}

This study was conducted with the approval of the Scientific Ethics Committee of Kafkas University Faculty of Medicine in the Department of Obstetrics and Gynecology between 01.03.2017 and 01.03.2018. (Approval No: 80576354-050-99/56, 01/03/2017). Informed consent was obtained from all women and approval was obtained from the Human Ethics Committee of Kafkas University. The principles of the Declaration of Helsinki were followed.

\section{Results}

A total of 77 primer infertile women with PCOS aged between the 20-35 years with a BMI between 20-30 $\mathrm{kg} / \mathrm{m}^{2}$ (non obese) were enrolled in this prospective case controlled clinical trial.

Age and body mass index (BMI) were similar in both groups ( $p=0.84, p=0.845)$. There were no differences in terms of duration of infertility and marriage, serum levels of LH, FSH, E2, P, PRL, TSH, AS, TT, and DHEAS between the groups. Total number of trials and number of antral follicles were significantly higher in the clomiphene citrate resistant group. While we compare the clomiphene citrate sensitive group with clomiphene citrate resistant group in resistant group plasma total antioxidant levels were significant low $(\mathrm{p}=0.001)$. Mean plasma total antioxidant levels were $1.21 \pm 0.42$ and $2.4 \pm 0.49 \mathrm{mmolTrolEq} / \mathrm{L}$ in clomiphene citrate resistant and sensitive group respectively (Table 1).

In the ROC curve analysis total antioxidant status value $\leq 1.66 \mathrm{mmol}$ Troloxequivalent/L were have predictability on resistance development with $93.75 \%$ sensitivity and $86.67 \%$ specificity (Figure 1 ). 
Table 1. Comparison of characteristics, and the concentration of TAS (mmolTrolEq/L) between cases regard to response to CC therapy

\begin{tabular}{|c|c|c|c|}
\hline Variables & Group 1: (CC sensitive) ( $\mathrm{N}=45)$ & Group 2: (CC resistant) $(\mathrm{N}=32)$ & $P$ value \\
\hline Female age (years) & $27.78 \pm 7.31$ & $28.13 \pm 7.72$ & 0.84 \\
\hline Male age (years) & $34.24 \pm 8.15$ & $34.59 \pm 8.11$ & 0.85 \\
\hline Duration of infertility (years) & $2.11 \pm 1.8$ & $3.12 \pm 2.77$ & 0.074 \\
\hline Marriage duration (years) & $6.22 \pm 1.78$ & $7.62 \pm 1.89$ & 0.062 \\
\hline $\mathrm{BMI}\left(\mathrm{kg} / \mathrm{m}^{2}\right)$ & $26.80 \pm 2.23$ & $27.11 \pm 2.45$ & 0.845 \\
\hline Total number of trials & $1.53 \pm 0.69$ & $3.75 \pm 0.43$ & $0.024^{*}$ \\
\hline FSH (mlU/ml) & $5.53 \pm 0.99$ & $5.68 \pm 0.96$ & 0.499 \\
\hline AF number & $15.3 \pm 2.59$ & $18.3 \pm 3.37$ & $0.043^{*}$ \\
\hline AS (ng/mL) & $5.66 \pm 1.04$ & $5.50 \pm 0.88$ & 0.464 \\
\hline $\mathrm{LH}(\mathrm{mlU} / \mathrm{mL})$ & $8.13 \pm 1.12$ & $8.53 \pm 0.56$ & 0.064 \\
\hline TAS (mmolTrolEq/L) & $2.40 \pm 0.49$ & $1.21 \pm 0.42$ & $0.001^{*}$ \\
\hline $\mathrm{TT}(\mathrm{ng} / \mathrm{dL})$ & $81.62 \pm 5.12$ & $83.24 \pm 5.56$ & 0.198 \\
\hline $\mathrm{E}_{2}(\mathrm{pg} / \mathrm{mL})$ & $47.02 \pm 19.54$ & $58.84 \pm 21.61$ & 0.462 \\
\hline Progesterone (ng/mL) & $1.84 \pm 0.47$ & $1.93 \pm 0.24$ & 0.313 \\
\hline DHEA-S $(\mu \mathrm{g} / \mathrm{dL})$ & $436.13 \pm 13.02$ & $438.22 \pm 17.21$ & 0.563 \\
\hline
\end{tabular}

AF, number of antral follicles; TAS, total antioxidant status; TT, total testosterone; BMI, body mass index; $\mathrm{E}_{2}$, estradiol; LH, luteinizing hormone; FSH, follicle stimulating hormone; AS, androstenedione. Values are given as mean \pm SD.

${ }^{*}$ Values expressing significance in the table are indicated as shift characters.

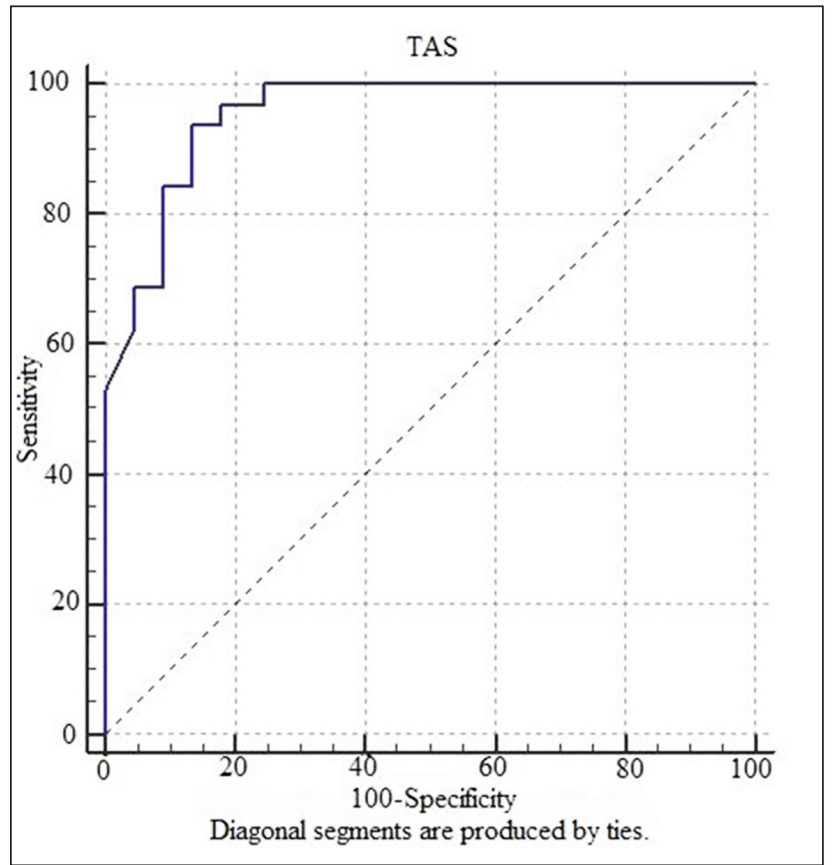

Figure 1. Receiver operating characteristic (ROC) curve analysis. To determine the critical values that could predict clomiphene citrate resistant, ROC curves were generated for total antioxidant levels. Receiver operating characteristic curves for serum total antioxidant levels (area under the curve [AUC], 0.956; standard error [SE], 0.0198; $P<0.001)$ for predicting clomiphene citrate resistant in PCO women.

\section{Discussion}

PCOS, a devastating diagnosis for women of reproductive age, is quite common. The causes of PCOS may vary, including genetic susceptibility, autoimmune and enzymatic disorders. Although PCOS diagnosis is relatively easy, management should be initiated immediately, especially in infertile patients. At the moment, clomiphene citrate is the one of first step treatment of anovulatory infertility. However, $20 \%$ to $25 \%$ of patients remain anovulatory after CC treatment ${ }^{19}$. The selection of patients with polycystic ovary disease who can benefit from CC therapy reduces the rate of failure and unnecessary costs.

The results of present study demonstrated that in CC sensitive group a marked correlation of elevated plasma total antioxidant levels when compared with the resistant group. For the prediction of CC resistance, the primary finding of the study demonstrated that when total antioxidant status cut-off value was taken $\leq 1.66 \mathrm{mmol}$ Troloxequivalent/L the best sensitivity of $93.75 \%$ and specificity of $86.67 \%$, were achieved respectively. 
Although, many studies have shown the relationship between oxidative stress and PCOS, an exact opinion has not been drawn regarding their probable association $^{20}$. High ROS levels in granulosa cells correlate with low oocyte fertilisation ability, low embryo quality and reduced implantation rates ${ }^{21}$. Oyawoye et al. have suggested that high levels of total antioxidant capacity could be used to predict fertilization potential ${ }^{22}$. Attaran et al. reported that the follicular fluid reactive oxygen species level at the physiological level might be indicative of the predicting in vitro fertilisation suc$\operatorname{cess}^{23}$. It is anticipated that oxidative parameters will be improved by giving antioxidant agents due to the negative effects of free radicals on female fertility. As a result, oxidative stress seems to relate to reproduction and development pathology. The importance of reactive oxygen species and antioxidants should be considered in the regulation of reproduction and fertilisation. The role of oxidative stress in fertility has demonstrated that fertility rates can be increased with antioxidant treatments ${ }^{24}$.

In a study conducted by Lai et al, which compared the in vitro fertilization and embryo transfer (IVF-ET) results of PCOS patients with tubal factor infertility by ROS levels, the PCOS group had slightly lower fertilisation, cleavage, grade I/II embryo, clinical pregnancy, and implantation rates, as well as a higher miscarriage rate than the tubal factor group $(P>0.05)$. They also found a significantly higher ROS level of granulosa cells in the PCOS group than in the tubal factor group $(P<0.05)^{25}$.

Verit et al demonstrated that levels of TAC could predict which patients could not ovulate after CC administration. In their study, total antioxidant capacity had the AUC value of (0.91) in CC-resistant anovulation $^{26}$. In this study, I found an AUC value of 0.956 , so my results are consistent with the results of this study.

Although studies indicate that the factors determining ovarian response to clomiphene citrate are age, obesity and hyperandrogenemia, we did not find a significant difference between these variables in our study because obese cases were already excluded ${ }^{27}$. We found that in the clomiphene citrate resistance group, the number of antral follicles was significantly higher $(P<0.05)$. Ovarian volume and menstrual regularity were among the factors that determined ovarian response to CC in a study conducted by Eijkemans et al. ${ }^{28}$. However we could not assess the relationship between menstrual pattern and CC resistance because all the patients in our study were oligo or amenorrheic. We also did not evaluate the ovarian volume in our study, but we found that the antral follicle number was significantly higher in the $\mathrm{CC}$ resistant group which can be accepted as an indirect finding of ovarian volume.

When we look at the literature, we observed that PCOS patients were compared with women who had no evidence of androgen excess and, in some cases, other metabolic disorders as a control group. One advantage of the present study was that both groups were selected from PCOS patients; this means that the current study was partially homogeneous. ROS production as a result of ovarian stimulation has been shown to cause oxidative stress and disrupt oxidant-antioxidant balance but in our study for ovulation induction we used CC in both groups, which was another advantage $^{29}$. This study is also the only study in the literature that evaluates the relationship between PCOS, and ovulation induction with CC and TAS leading to wider studies to perform thereafter.

The small sample size is a limitation of the present study. An other one is that CC dose didn't rise up to $250 \mathrm{mg}$ as recommended in literature. So, it is necessary to put forward a new optimizing method for diminishing the impact of various stimulation protocols thoroughly and then assess the changes.

\section{Conclusion}

Current study found that total antioxidant levels were significantly lower in the clomiphene resistant group so I believe that the measurement of total antioxidant level before clomiphene citrate treatment can helps to select the appropriate ovulation induction protocol in polycystic ovary syndrome patients. This study demonstrates the rationale for continuing with a prospective study to determine the positive and negative predictive values of these measures in clinical practice. Ability to diagnose the patient by measuring total antioxidant capacity (TAC) at the time of admission to the hospital whether they will clomiphene citrate sensitive or not make a significant contribution to current clinical care.

\section{Acknowledgements}

Thanks to the participants for their interest. This study was not funded by any organisation. The author thanks to Associate Professor Doctor Binali Çatak for his statistical analysis help. 


\section{References}

1. March WA, Moore VM, Willson KJ, Phillips DI, Norman RJ, Davies MJ. The prevalence of polycystic ovary syndrome in a community sample assessed under contrasting diagnostic criteria. Hum. Reprod 2010;25:544-551.

2. Pandey V, Singh A, Krishna A, Pandey U, Tripathi YB. Role of oxidative stress and lowgrade inflammation in letrozoleinduced polycystic ovary syndrome in the rat. Reprod Biol 2016;16(1):70-7.

3. Rojas J, Chavez M, Olivar L, Rojas M, Morillo J, Mejias J, et al. Polycystic ovary syndrome, insulin resistance, and obesity: navigating the pathophysiologic labyrinth. Int J Reprod Med 2014;2014:719050.

4. Fenkci V, Fenkci S, Yilmazer M, Serteser M. Decreased total antioxidant status and increased oxidative stress in women with polycystic ovary syndrome may contribute to the risk of cardiovascular disease. Fertil Steril 2003;80(1):123-127.

5. Deepika ML, Nalini S, Maruthi G, Ramchander V, Ranjith K, Latha KP, et al. Analysis of oxidative stress status through MN test and serum MDA levels in PCOS women. Pakistan J Biol Sci 2014; 17:574.

6. Olusi SO. Obesity is an independent risk factor for plasma lipid peroxidation and depletion of erythrocyte cytoprotectic enzymes in humans. Int $\mathrm{J}$ Obes Relat Metab Disord 2002;26:1159-1164.

7. Urakawa H, Katsuki A, Sumida Y. Oxidative stress is associated with adiposity and insulin resistance in men. J Clin Endocrinol Metab 2003;88:4673-4676.

8. Duleba AJ, Dokras A. Is PCOS an inflammatory process? Fertil Steril 2012;97:7-12.

9. Vincent HK, Taylor AG. Biomarkers and potential mechanisms of obesity-induced oxidant stress in humans. Int J Obes 2005;30:400-418.

10. Liu S, Navarro G, Mauvais-Jarvis F. Androgen excess produces systemic oxidative stress and predisposes to beta-cell failure in female mice. PLoS One 2010;5: e11302.

11. Murri M, Luque-Ramirez M, Insenser M, Ojeda-Ojeda M, Escobar-Morreale HF. Circulating markers of oxidative stres and polycystic ovary syndrome (PCOS): a systematic review and meta-analysis. Human Reproduction Update 2013;19:268288.

12. Moti M, Amini L, Ardakani SSM, Kamalzadeh S, Masoomikarimi M. Oxidative stress and anti-oxidant defense system in Iranian women with polycystic ovary syndrome. Iran J Reprod Med 2015;13:373-378.

13. Nunez-Calonge R, Cortes S, Gutierrez Gonzalez LM. Oxidative stress in follicular fluid of young women with low response compared with fertile oocyte donors. Reprod Biomed Online 2016;32:446-456.

14. Yilmaz N, Inal HA, Gorkem U, Sargin Oruc A, Yilmaz S, Turkkani A. Follicular fluid total antioxidant capacity levels in PCOS. J Obstet Gynaecol 2016;6:654-657.
15. Turrens JF. Mitochondrial formation of reactive oxygen species. J Physiol 2003;552:335-344.

16. Agarwal A, Gupta S, Sharma RK. Role of oxidative stress in female reproduction. Reprod Biol Endocrinol 2005;3:28.

17. Homburg R. Clomiphene citrate- end of era? A mini review. Hum Reprod 2005;20:2043-2051.

18. Erel O. A Novel automated method to measure total antioxidant response against potent free radical reactions. Clin Biochem 2004;37:112-119.

19. Mitwally MF, Casper RF. Use of an aromatase inhibitor for induction of ovulation in patients with an inadequate response to clomiphene citrate. Fertility and sterility, 2001;75(2):305309.

20. Yeon Lee J, Baw CK, Gupta S, Aziz N, Agarwal A. Role of oxidative stress in polycystic ovary syndrome. Curr Women's Health Rev 2010;6:96-107.

21. Jancar N, Kopitar AN, Ihan A, Klun IV, Bokal EV. Effect of apoptosis and reactive oxygen species production in human granulosa cells on oocyte fertilization and blastocyst development. J Assist Reprod Genet 2007;24:91-7.

22. Oyawoye O, Abdel Gadir A, Garner A, Constantinovici N, Perrett C, Hardiman P. Antioxidants and reactive oxygen species in follicular fluid of women undergoing IVF. relationship to outcome. Hum Reprod 2003;18:2270-2274.

23. Attaran M, Pasqualotto E, Falcone T. The effect of follicular fluid reactive oxygen species on the outcome of in vitro fertilization. Int J Fertil Womens Med 2000;45:314-20.

24. Bedaiwy MA, Falcone T, Mohamed MS. Differential growth of human embryos in vitro: role of reactive oxygen species. Fertil Steril 2004;82:593-600.

25. Lai Q, Xiang W, Li Q. Oxidative stress in granulosa cells contributes to poor oocyte quality and IVF-ET outcomes in women with polycystic ovary syndrome. Frontiers of medicine 2017;1-7.

26. Verit FF, Erel O, Kocyigit A. Association of increased total antioxidant capacity and anovulation in nonobese infertile patients with clomiphene citrate-resistant polycystic ovary syndrome. Fertility and sterility 2007;88(2):418-424.

27. Imani B, Eijkemans MJ, te Velde ER, Habbema JDF, Fauser B. CA nomogram to predict the probability of live birth after clomiphene citrate induction of ovulation in normogonadotropic oligoamenorrheic infertility. Fertility and sterility 2002;77:91-97.

28. Eijkemans MJ, Habbema JD, Fauser BC. Characteristics of the best prognostic evidence: an example on prediction of outcome after clomiphene citrate induction of ovulation in normogonadotropic oligoamenorrheic infertility. Semin Reprod Med 2003;21:39-47.

29. Palini S, Benedetti S, Tagliamonte MC. Influence of ovarian stimulation for IVF/ICSI on the antioxidant defence system and relationship to outcome. Reprod Biomed Online 2014;29:65-71. 